\title{
The Gender Unemployment Gap: How the 2008-2009 Economic Crisis in Ecuador Differentially Affected Women
}

\author{
By Cinthia Josette Arévalo Gross
}

This paper uses panel data to assess how the 2008-2009 economic crisis affected the unemployment rates of Ecuadorian men and women differently. After controlling for individual characteristics, the results of a difference-in-differences model and individual and household fixed effects models indicate that women were one to two percentage points more likely than men to be unemployed during the economic crisis in Ecuador. This paper concludes, therefore, that the economic crisis negatively affected women more than men even after controlling for observed and unobserved time-invariant individual characteristics.

\section{Introduction}

The United States' Great Recession had an international impact, evidenced by the recessions that many European Union countries faced by mid-2008, as well as recessions in several other countries. The global impact of the Great Recession is significant because 2009 was the first year of global recession since World War II (Verick and Islam 2010, 3). Moreover, the damaging effects of the US recession were also felt by developing countries by the end of 2008 . Ecuador, for instance, experienced a negative GDP growth rate during the last quarter of 2008 and in the first two quarters of 2009, and an increase in the unemployment rate from 6.9 percent in March 2008 to 8.6 percent in March 2009 (see Figures 1 and 2). The Ecuadorian 2008-2009 economic crisis also impacted the unemployment rate among women significantly more than it did among men, widening the gender employment gap. Because there are various explanations for gender differences in labor market outcomes, an analysis of this crisis is necessary for determining whether there were any gender differences that cannot be explained by individual characteristics, such as human capital investments. The goal of this paper, therefore, is to determine to what extent, if any, Ecuadorian women were more negatively affected than men by the 2008-2009 crisis after controlling for individual characteristics.

This paper is structured in five parts. The first section briefly reviews the theory related to gender differential effects in the labor force and briefly reviews papers that assess how economic crises affect women's and men's unemployment rates differently. The second section provides information about the context of the economic crisis and some descriptive statistics. The third section describes the data and the methodology used to assess whether men and women experienced different labor market effects during the 2008-2009 economic crisis in Ecuador. The fourth section summarizes the econometric analysis 
results. Lastly, the fifth section synthesizes, comments on the major findings, and describes the policy implications of these findings.

\section{Theory and Literature Review}

This section presents an overview of the "preferences/human capital" theory that provides explanations for gender differences in labor market outcomes. This is followed by a brief review of the literature about how economic crises affect men and women differently. Lastly, this section reviews more recent empirical studies that analyze the gender differential effects of economic crises in labor market outcomes.

The "preferences/ human capital" hypothesis laid out by Altonji and Blank (1999) is considered one of the prominent theories regarding the origin of race and gender differences in labor market outcomes, and is the basis underlying most empirical research on this topic. Within this framework, race and gender differences in labor outcomes derive from differences in group preferences, comparative advantage, and human capital investments. Any residual difference in labor market outcomes not explained by these factors is assumed to be the result of discrimination. (Altonji and Blank 1999, 3164).

Altonji and Blank's first major explanation of race and gender differences in labor market outcomes is related to different preferences across groups. This explanation argues that men and women may differ in their preferences for certain types of jobs. Gender differences in labor market outcomes, then, may be the result of employers giving more value to certain types of jobs that tend to be preferred by men than positions typically preferred by women. Thus, the ways in which employers value certain jobs over others can help determine how men and women are represented in different occupations and how wages vary across occupations (Altonji and Blank 1999, 3165). It is important to mention, however, that preference differences between men and women may also be the result of premarket gender discrimination-for instance, in the educational system.

Altonji and Blank indicate that differences in labor market outcomes may also be due to differences in comparative advantage. Becker, Mincer and other researchers argue that women's comparative advantage in home production could be founded on biologically based differences in gender roles in reproduction (Becker 1991; Altonji and Blank, 3166). Additionally, Becker (1991) argues that parental investments in their daughters' skills amplify this comparative advantage, in part because women's home production skills are expected to be rewarded in a marriage market characterized by men who have prepared for the labor market.

"Differences in human capital investment" is the final explanation put forth by Altonji and Blank. Similar to comparative advantage, this theory states that the expected return for investments in human capital may differ by gender if women expect to work full-time for fewer years than men do. So, based on their expected returns, human capital investments may vary by gender. In addition, prelabor market gender discriminationwhich affects quality of schooling, fields of study, and access to higher education-reduces women's human capital investments. (Altonji and Blank 1999, 3167). Thus, differences in pre-market human capital accumulation could be partly responsible of the earnings gap between men and women.

A number of authors examining gender differences during eco- 
nomic crises argue that women represent a "reserve army" of labor that is incorporated into the labor force during economic expansion and laid off during recession (Bruegel 1979, Power 1983). In other words, women are incorporated into the labor force only when the labor supply is scarce. During World War II in the United States, for example, women were pulled into the labor force. When the men fighting in the war returned home, many of these women were pushed out of the labor force. Irene Bruegel (1979) provides empirical evidence for the theory that women serve as a reserve army of labor during periods of economic crisis. Through an analysis of trends in female employment in Britain, Bruegel argues that women are more susceptible to redundancy and unemployment than men in an equivalent situation. In addition, Bruegel explains that despite the growth of women's participation in paid work, economic cycles can affect this progress. Bruegel indicates that in every economic downturn in Britain since World War II, growth in the rate of female employment declined relative to the growth rate in periods of economic growth. Moreover, between 1974 and 1977-a period of overall employment decline- the rate of employment decline was greater for women than for men in every industry with substantial female labor participation (Bruegel 1979, 16). Similarly, some authors argue that if women generally have lower skill levels, employers are likely to retain more skilled men when work slows since men's skills are harder to replace. As MacKay et al. (1971) explain, employers are less cautious about firing workers with low skills levels since these workers can be more easily replaced when trade picks up. In contrast to Bruegel's findings, Ruth Milkman (1976) provides arguments against the "reserve army of labor" theory. Milkman examines how the Great Depression affected women's remunerated and non-remunerated work in the United States. According to her study, while economic expansion pulls women into the labor force, gender division of labor gives less flexibility to the labor market and thus prevents women from being displaced during a recession. Using data from the 1930 Census, Milkman finds that economic contraction has less of an effect on women's participation in the paid labor force than men's. This finding, which contradicts the theory that women are an expendable reserve army of labor, is explained by the fact that the occupations in which women were concentrated (occupations that were traditionally considered "feminine") contracted less than those occupied by men. In other words, gender differences in labor market outcomes were explained by differences in job preference and human capital investments, as well as gender division of labor.

The discussion of how economic crises affect women and men differently continues to be relevant in the twenty-first century. Joseph Lim (2000) provides important insights about the effects of an economic crisis not only on employment but also on the amount of time available for leisure. Lim (2000) examines the differential impacts that the 1997-1998 Asian crisis had on men and women in the Philippines and considers the effects of prior periods with cycles of economic expansion and contraction and an increase in trade openness. Comparing employment, underemployment, unemployment, and labor force participation statistics of men and women in the Philippines from 1981 to 1998, Lim's (2000) study shows that during a period of economic growth-in the second half of 
the 1980s-male employment grew more than female employment. Lim also demonstrates that the economic slowdown caused by the Asian economic crisis reversed this process: The unemployment rate increased more among men than among women. One possible explanation for this result is that sectors of the economy dominated by women-community, social services, and sales-were more flexible during the recession. In addition, Lim states that the increase in female labor force participation, along with longer working hours for women relative to men, is evidence that increased female employment can be viewed as an adjustment mechanism during economic crises. Lim concludes, therefore, that macroeconomic cycles are not gender neutral and that they also contribute to increasing wage gaps between men and women. The study also indicates that during the economic crisis in the Philippines, women tended to work more hours (at their workplaces and in the home/ unpaid work) than men did, so inequality in the time available for leisure or other activities also increased (Lim 2000).

Lastly, two papers from Latin America provide insights about regional trends in differences in labor market outcomes due to gender. In both Brazil and Ecuador, women were more negatively affected by economic crises than men. Decreased labor force participation in Brazil during the 2008-2009 crisis may have been an adjustment mechanism: during crises, women tend to become economically inactive and resort to unpaid household work (Observatório Brasil Igualdade de Gênero 2009). Allison Vásconez (2005) describes the effect of the 1999 economic crisis on employment and poverty among Ecuadorians. Vásconez explains that both the economic crisis and an economic liberalization process simultaneously affected, and were affected by, labor and income gaps. Based on indicators of women's employment and poverty levels during the 1990s, Vásconez's analysis indicates that in times of economic crisis, labor participation and unemployment rates increase more for women than for men.

Arévalo Gross (2011) evaluates the differential effect of the 2008-2009 economic crisis on female and male employment rates in Ecuador. Using longitudinal data, the paper assesses the change in employment status between 2008 and 2009 for men and women, controlling for personal characteristics such as race, education, province, and age, among others. The study concludes that the crisis had a differential effect for men and women: Women were more likely to lose jobs and less likely to find new jobs than men. In addition, relative to men, women had lower probabilities of being formally employed and of being economically active, and they experienced a higher increase in the time spent doing housework and household chores. Specifically, Arévalo Gross's results indicate that women had a 1.4 percentage points higher probability of losing their jobs than men did during the 2008-2009 economic crisis. The study, however, has limitations related to the internal validity of the results since it only controls for a limited number of observable individual characteristics in 2008 and assumes that individuals' characteristics did not change between years. This study addresses some of these limitations.

\section{Context and Descriptive Statistics}

The global economic crisis of 2008-2009 affected countries worldwide in different magnitudes and for different lengths of time. In the Ecuadorian case, as Figure 1 shows, the 
Figure 1: Quarterly Real GDP Growth Rate in Ecuador

$5.0 \%$

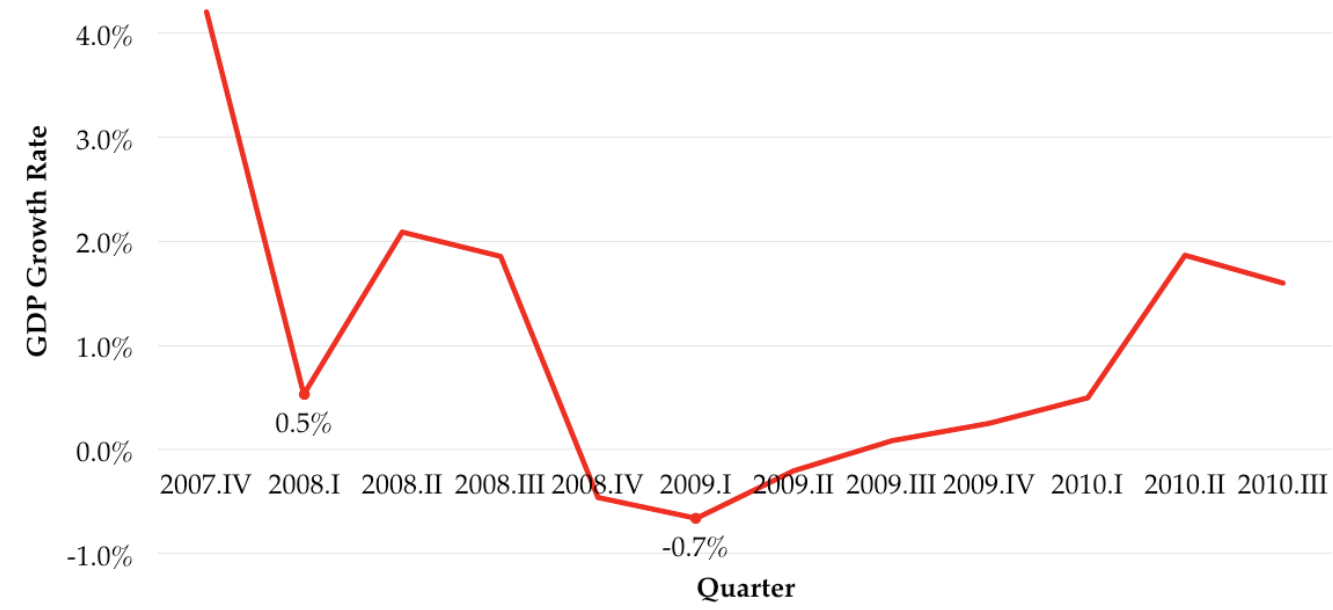

Source: Banco Central de Ecuador (2011) (real GDP growth rate in 2000 USD, (t/ t-1)).

Figure 2: Quarterly Unemployment Rate in Ecuador

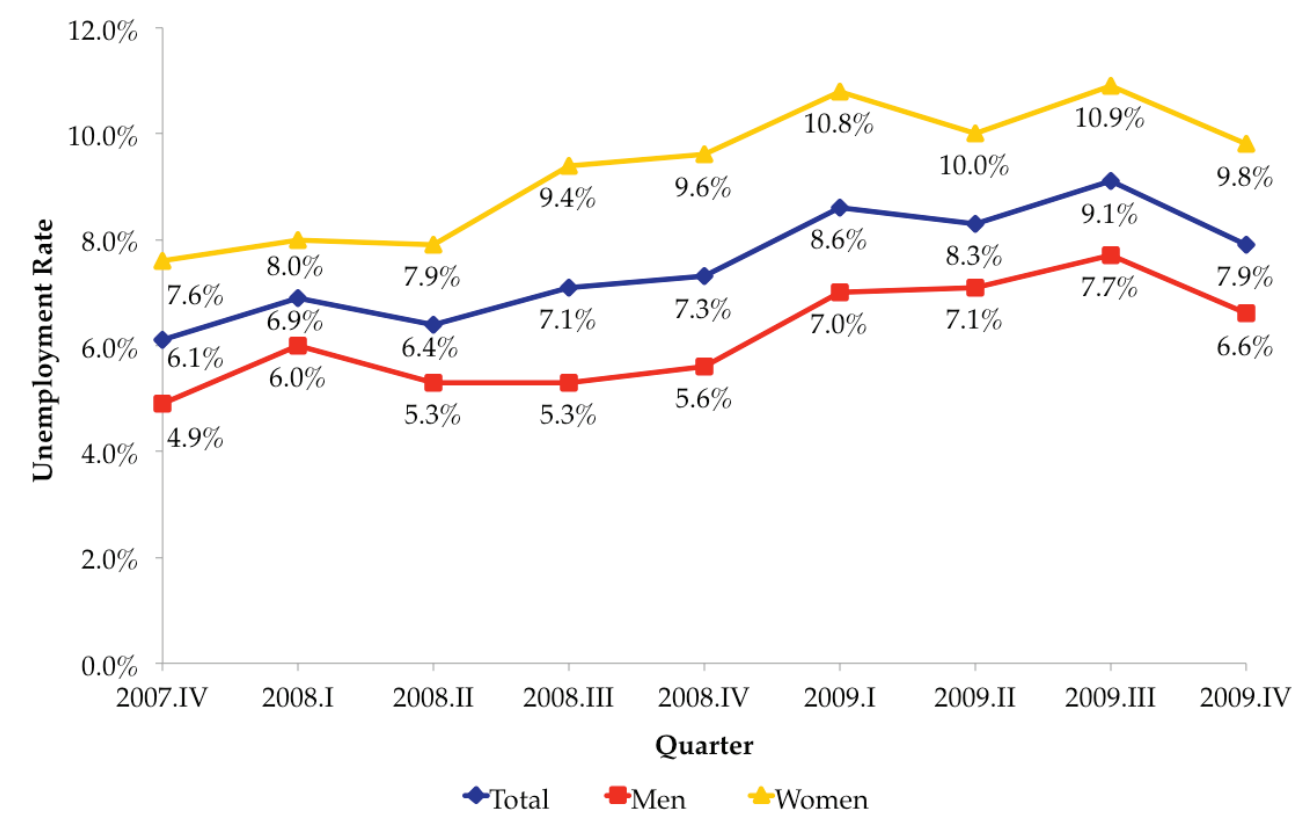

Source: INEC-ENEMDU December 2007-December 2009. 
country had a negative quarterly GDP growth rate starting in the last quarter of 2008, continuing through the second quarter of 2009. At the same time that Ecuador's GDP declined, its unemployment rate rose, increasing from 6.9 percent in March 2008 to 8.6 percent in March 2009. As Figure 2 shows, the unemployment rate for women increased by 2.8 percentage points during that period while the unemployment rate for men increased one percentage point.

The National Institute of Statistics and Census (INEC) of Ecuador provides official definitions of labor indicators. One significant indicator is the Economically Active Population (EAP), defined as the number of people of working-age (people 10 years or older) who worked at least one hour during the reference week, people who have a job, or people who are available to work and searching for a job (the unemployed). The EAP includes the employed and unem- ployed working-age population, but excludes the economically inactive population (e.g., students, retirees, and other people who are not searching for a job, among others). INEC defines the rate of full employment as the percentage of the EAP who work at least 40 hours per week and / or earn at least the minimum wage, or those who work less than 40 hours per week but earn more than the minimum wage and are not seeking to work for more hours. INEC considers a person underemployed if the individual worked during the reference period and wanted to increase their number of work hours or productivity but was unable to do so. Lastly, Global Labor Participation (GLP) is defined as the percentage of the working-age population that is economically active (EAP/ workingage population).

Table 1 displays descriptive statistics related to labor and employment in Ecuador between March 2008

Table 1: Labor Statistics and Descriptive Statistics, March 2008 and 2009

\begin{tabular}{|c|c|c|c|c|c|c|c|c|}
\hline & \multicolumn{3}{|c|}{ March 2008} & \multicolumn{3}{|c|}{ March 2009} & \multicolumn{2}{|c|}{ Diff. $2009-2008$} \\
\hline & Men & Women & $\begin{array}{l}\text { Diff. Men - } \\
\text { Women }\end{array}$ & Men & Women & $\begin{array}{l}\text { Diff. Men - } \\
\text { Women }\end{array}$ & Men & Women \\
\hline Unemployed & $5.40 \%$ & $7.10 \%$ & $-1.70 \%$ ** & $6.20 \%$ & $9.70 \%$ & $-3.50 \%$ *** & $0.80 \%$ & $2.50 \%$ *** \\
\hline Fully Employed & $44.80 \%$ & $31.10 \%$ & $13.70 \%^{* * *}$ & $43.80 \%$ & $32.00 \%$ & $11.80 \% \%^{* * *}$ & $-1.00 \%$ & $0.90 \%$ \\
\hline Underemployed & $48.00 \%$ & $60.60 \%$ & $-12.60 \% \%^{* * *}$ & $49.40 \%$ & $58.00 \%$ & $-8.60 \%^{* * *}$ & $1.40 \%$ & $-2.60 \%$ ** \\
\hline $\begin{array}{l}\text { Hours of House- } \\
\text { hold Work Per } \\
\text { Week }\end{array}$ & 8.14 & 25.28 & $-17.14^{\star * *}$ & 8.51 & 27.08 & $-18.57^{\star \star \star}$ & $0.37^{\star}$ & $1.80^{* * *}$ \\
\hline $\begin{array}{l}\text { Global Labor } \\
\text { Participation }\end{array}$ & $70.70 \%$ & $51.10 \%$ & $19.70 \%{ }^{* * *}$ & $71.60 \%$ & $51.20 \%$ & $20.40 \%^{* * *}$ & $0.90 \%$ & $0.20 \%$ \\
\hline $\begin{array}{l}\text { Marital Status: } \\
\text { Single }\end{array}$ & $48.20 \%$ & $50.70 \%$ & $-2.50 \%{ }^{* * *}$ & $49.50 \%$ & $52.50 \%$ & $-3.00 \%{ }^{* * *}$ & $1.30 \%$ & $1.80^{* *}$ \\
\hline $\begin{array}{l}\text { Educational At- } \\
\text { tainment (years) }\end{array}$ & 9.65 & 9.37 & $0.28^{\star * *}$ & 9.87 & 9.58 & $0.30^{\star * *}$ & $0.22^{* * *}$ & $0.21^{* * *}$ \\
\hline
\end{tabular}

$* 90 \%$, ** $95 \%$, *** $99 \%$ confidence level (t-tests).

Notes: $\%$ unemployed $=$ unemployed people $/$ EAP, global labor participation $=\mathrm{EAP} /$ working age population

Source: ENEMDU March 2008 and March 2009 panel sample. 
and March 2009 (ENEMDU panel sample). The table shows that women had lower levels of employment than men in both 2008 and 2009 and that the gap between male and female employment increased between March 2008 and March 2009. Similarly, while women's unemployment rate increased by 2.5 percentage points over the course of the economic crisis, men's unemployment rate had no statistically significant change. The difference in the differences is 1.7 percentage points. These results, like those found in Vásconez's (2005) study, indicate that the employment rate decreased more for women than for men during Ecuador's 2008-2009 economic crisis.

As shown in Table 1, there was no significant change in full employment between March 2008 and March 2009 for either men or women, while women's underemployment decreased in a statistically significant way. The data in Table 1 also reveal that women worked about three times more unpaid hours in the household per week than men did in 2008, and that this gap increased after the economic crisis. From March 2008 to March 2009, unpaid household work increased by 1.8 hours per week for women, while for men it only increased by 0.37 hours per week. These results are similar to those found in Lim's (2000) study, which states that women tend to work more unpaid household hours than men do during periods of economic crisis. These findings imply that the economic crisis increased the inequality of the number of hours available for leisure or other activities between men and women.

Lastly, Table 1 shows that although there is a significant gender gap in GLP for both years, there was no significant change between March 2008 and March 2009. This is important for the analysis of unemploy- ment rates because unemployment is measured in reference to the EAP. Thus, the changes in the unemployment rates described above cannot be attributed to changes in the composition of the economically active population.

\section{Data and Methodology}

The data used in this study are from the National Survey of Employment and Unemployment (ENEMDU), a national employment survey that INEC conducts. The sample in the survey is representative of the population at the nationalurban level. The panel for March 2008 and March 2009 contains information for 13,896 individuals, which is only a portion of the whole sample. The panel dataset was constructed by merging March 2008 and March 2009 data by matching the information of individuals using a unique identifier.

This paper analyzes the differential effect in employment between men and women from March 2008 to March 2009 in Ecuador using panel data methods. Using rearranged panel data, the techniques used to assess the differential effect in employment between men and women are a difference-in-differences model, individual and household fixed effects models, and a random effects model. The methodology tries to overcome some internal validity concerns of Arévalo Gross's (2011) paper, such as omitted variable bias, by controlling for time-invariant characteristics. Using this methodology, it is possible to determine whether the economic crisis had gender differential effects that cannot be explained by other individual characteristics, such as human capital investment.

The difference-in-differences model, with gender and year indicator variables, is represented by the following equation 
(1) Unemp $_{i t}=\beta_{0}+\beta_{1}$ Female $_{i}+$ $\beta_{2}$ Year $2009_{i t}+\beta_{3}$ Female * $^{i}$ ear $2009_{i t}$ $+\beta_{4} X_{i t}+\varepsilon_{i t}$

where

Unemp is a dummy variable that equals 1 if individual $i$ is unemployed in year $t$ and 0 if individual $i$ is employed in year $t$,

Female is a dummy variable that equals 1 if individual $i$ is female and 0 if individual $i$ is male,

Year2009 is a dummy variable that equals 1 if time $t$ is March 2009 and 0 if time $t$ is March 2008,

$X_{i t}$ is a vector of control variables, and

$\beta_{3}$ indicates the differential effect of the crisis year between men and women.
The difference-in-differences model that incorporates year and individual fixed effects is represented by the following equation

(2) Unemp $_{i t}=\beta_{0}+\beta_{1}$ Year2009 $_{i t}+$ $\beta_{2}$ Female * Year2009 ${ }_{i t}+\beta_{3} X_{i t}+a_{i}+u_{i t}$

where

$a_{i}$ is the unobserved, time-invariant individual effect;

in this model, the gender dummy variable is dropped due to the nature of the fixed effects model;

$u_{i t}$ is the idiosyncratic error or time-varying error and represents unobserved factors that change over time and affect unemployment; and

$\beta_{2}$ indicates the differential effect of the crisis year between men and women.

\section{Table 2: Regression Results on Unemployment (Difference-in-Difference} Models)

\begin{tabular}{|c|c|c|c|c|c|}
\hline Coefficient & (1) & (2) & (3) & (4) & (5) \\
\hline Women & $\begin{array}{l}0.0174^{* * *} \\
(0.0050)\end{array}$ & & & $\begin{array}{c}0.3316^{* * *} \\
(0.0060)\end{array}$ & $\begin{array}{c}0.3072^{* * *} \\
(0.0060)\end{array}$ \\
\hline Year2009 & $\begin{array}{c}0.0076 \\
(0.0050)\end{array}$ & $\begin{array}{l}-0.0014 \\
(0.0040)\end{array}$ & $\begin{array}{l}-0.0012 \\
(0.0040)\end{array}$ & $\begin{array}{c}0.0042 \\
(0.0040)\end{array}$ & $\begin{array}{c}0.0028 \\
(0.0040)\end{array}$ \\
\hline Women*Year2009 & $\begin{array}{l}0.0177^{* *} \\
(0.0080)\end{array}$ & $\begin{array}{c}0.0125^{*} \\
(0.0070)\end{array}$ & $\begin{array}{l}0.0125^{*} \\
(0.0070)\end{array}$ & $\begin{array}{l}0.0153^{* *} \\
(0.0070)\end{array}$ & $\begin{array}{l}0.0142^{*} \\
(0.0070)\end{array}$ \\
\hline Number of Observations & 16,908 & 16,908 & 16,839 & 16,908 & 16,839 \\
\hline R-squared & 0.0038 & 0.7494 & 0.7498 & 0.3230 & 0.3380 \\
\hline Individual Fixed Effects & & Yes & Yes & & \\
\hline $\begin{array}{l}\text { Time-Variant Controls (marital sta- } \\
\text { tus and educational attainment) }\end{array}$ & & & Yes & & Yes \\
\hline Household Fixed Effects & & & & Yes & Yes \\
\hline
\end{tabular}

Numbers in parentheses are robust and clustered (at the individual and household levels when applicable) standard errors. * $90 \%, * * 95 \%, * * * 99 \%$ confidence level (t-tests). 
By including individual fixed effects, the model controls for all time-invariant observable and unobservable individual characteristics. Thus, the model removes a potentially large source of omitted variable bias.

As an additional check, a regression with household-level fixed effects was performed. Performing this type of regression also allows the gender dummy variable to remain in the model.

\section{Results}

Table 2 displays the results of the aforementioned specifications. The results indicate that women were 1.25 to 1.76 percentage points more likely to be unemployed than men during Ecuador's economic crisis. In all of the model specifications, the coefficient on the interaction between women and the year 2009 is statistically significant at the 90 percent confidence level, sometimes at the 95 percent confidence level. These results are similar to the ones found in Arévalo Gross (2011); this paper, therefore, confirms the robustness of Arévalo Gross's (2011) initial results.

The first specification shows the results of the simple differencein-differences regression with no additional controls. The coefficients indicate that women had a 1.74 percentage points higher probability of being unemployed than men did in 2008 and that the probability of being unemployed in 2009 increased by 1.77 percentage points for women relative to men.

The second specification shows the results of a difference-indifferences regression with individual fixed effects. Controlling for all timeinvariant factors, the probability of being unemployed increased 1.25 percentage points more for women than for men in 2009. The interaction coefficient of this model is statistically significant at the 90 percent level. The third specification adds some time-variant controls to the individual fixed effects model, such as marital status and educational attainment. The coefficient does not change compared to the second specification and is statistically significant at the 90 percent level.

The fourth specification includes household-level fixed effects. This model controls for all factors at the household level that did not change over time. Within the same households, women had a higher probability of being unemployed than men did, and the probability of being unemployed increased 1.53 percentage points more for women than for men in 2009. The fifth specification adds additional controls, such as marital status and educational attainment. The results are similar to the fourth specification, although the coefficient of the interaction variable is now only statistically significant at the 90 percent level.

As a robustness check, a random effects regression analysis was also performed to assess the effect of specific time-invariant characteristics in the model. Nevertheless, the Hausman Test indicates that there is a correlation between the individual effects and the independent variables; thus the fixed effects model is preferred.

\section{Conclusion}

The results of this study indicate that the 2008-2009 economic crisis affected women more negatively than men even after controlling for observed and unobserved time-invariant individual characteristics. Further analysis with data from a wider time range is necessary to assess whether these findings were the effect of a national trend. Furthermore, while the difference-in-differences 
model with fixed effects controlled for all time-invariant observed and unobservable characteristics, unobservable time-variant characteristics that affect unemployment could pose a threat to the validity of these results.

The results of the econometric models performed in this study corroborate Arévalo Gross's (2011) earlier findings that, in Ecuador, there was a differential effect between men and women in the probability of being unemployed during the 2008-2009 economic crisis. The results indicate that women had a 1.25 to 1.76 percentage points higher probability of being unemployed than men did during the 2008-2009 economic crisis in Ecuador. These results are similar to Arévalo Gross's (2011) original finding that women in Ecuador faced a 1.4 percentage points higher probability of unemployment during the 2008-2009 economic crisis. This paper, therefore, confirms the robustness of the original results.

The results also indicate that there is still an unexplained gender differential impact on unemployment after controlling for time-invariant characteristics. This finding negates alternative explanations that gender differences in human capital and skills are solely responsible for differences in labor market outcomes since the fixed effects model controls for all time-invariant characteristics (which include skills and preferences). Discrimination is one possible explanation for the remaining differences in unemployment rates; as Altonji and Blank (1999) note, the residual difference that exists in labor market outcomes that cannot be explained by differences in human capital or preferences can be assumed to be due to discrimination. It is important, therefore, to perform further analyses to determine why economic crises affect men and women differently.

These findings have several policy implications. Policymakers should consider that economic crises have effects that are not gender neutral and that might not be explained solely by differences in skills and investments in human capital. These factors are especially important to acknowledge when designing policies that respond to the needs of the population during a recession. Women not only already have higher unemployment rates in Ecuador; their probability of being unemployed may increase even further when there is an economic crisis, as it did during the 2008-2009 economic crisis. This trend should be considered when designing policies aimed to ameliorate economic crises' effects.

\section{References}

Altonji, Joseph G., and Rebecca M. Blank. 1999. "Race and Gender in the Labor Market." In Handbook of Labor Economics, edited by Orley Ashenfelter and David Card, 3143-3259. New York: Elsevier.

Arévalo Gross, Cinthia Josette. 2011. “Mujeres, Trabajo y Crisis: Análisis con Enfoque de Género Sobre Variables de Trabajo en un Contexto de Crisis en Ecuador." MA diss., FLACSO-Ecuador.

Banco Central de Ecuador. 2011. “Boletin Cuentas Trimestrales Diciembre 2010." Accessed April 2, 2011. http:/ / contenido.bce.fin.ec/home1/estadisticas / cntrimestral/CNTrimestral.jsp.

Becker, Gary S. 1991. A Treatise on the Family, Enlarged Edition. Cambridge, MA: Harvard University Press. 
Bruegel, Irene. 1979. “Women as a Reserve Army of Labour: A Note on Recent British Experience." Feminist Review 3:12-23.

INEC (Instituto Nacional de Estadística y Censos). 2009. “Conceptos y Definiciones." Accessed November 12, 2014. http:/ / www.inec.gob.ec/ estadisticas /index.php?option=com_content\&view=article\&id=278\&Itemi $\mathrm{d}=57$ \&lang $=$ es.

2010. “Evolución del Mercado Laboral en el Ecuador: Resumen

Trimestral." Accessed November 2014. http: / / www.ecuadorencifras.gob.ec/documentos/web-inec/EMPLEO/Informacion-2010-2011-2012-2013/2010/Diciembre2010/Evoluci\%f3n\%20 del\%20Mercado\%20Laboral\%20a\%20Diciembre\%202010.pdf.

Lim, Joseph. 2000. "The Effects of the East Asian Crisis on the Employment of Women and Men: The Philippine Case." World Development 28(7):12851306.

MacKay, D.I., D. Boddy, J. Brack, J.A. Diack, and N. Jones. 1971. Labour Market Differences under Different Employment Conditions. London: George Allen \& Unwin.

Milkman, Ruth. 1976. “Women's Work and the Economic Crisis: Some Lessons of the Great Depression." Review of Radical Political Economics 8:73-97. http:/ / rrp.sagepub.com/cgi/content/abstract/8/1/71.

Observatório Brasil Igualdade de Gênero. 2009. “Observatório Brasil Igualdade de Gênero Estuda Primeiros Impactos da Crise Econômica Sobre as Mulheres." Accessed December 7, 2009. http: / / www.observatoriodegenero.gov.br/menu/ noticias / observatorio-brasil-igualdade-de-genero-estuda-primeiros-impactos-da-crise-economica-sobre-as-mulheres.

Power, Marilyn. 1983. "From Home Production to Wage Labor: Women as a Reserve Army of Labor." Review of Radical Political Economics 15(1):7191.

Vásconez, Alison. 2005. "Mujeres, Trabajo y Pobreza” in Mujeres Ecuatorianas: Entre las Crisis y las Oportunidades 1990-2004, edited by Mercedes Prieto, 249-314. Quito, Ecuador: Facultad Latinoamericana de Ciencias Sociales.

Verick, Sher, and Iyanatul Islam. 2010. “The Great Recession of 2008-2009: Causes, Consequences and Policy Responses." IZA Discussion Paper 4934. Bonn, Germany: Institute for the Study of Labor. http: / / ftp.iza. org/dp4934.pdf.

Cinthia Josette Arévalo Gross is a Public Policy and Administration PhD candidate and a Research Assistant at the George Washington University. Her fields of study are program evaluation and international development. Josette earned a bachelor's degree in Economics and Finance from Universidad San Francisco de Quito, a master's degree in Development Economics at the Latin American Faculty of Social Sciences, FLACSO-Ecuador, and a master's degree in Public Policy at GWU as an Ecuador Fulbright Scholar. Prior to pursuing graduate studies in the United States, Josette worked as a Monitoring and Evaluation Analyst in the Ecuadorian public sector. 
The author thanks the Policy Perspectives editorial team, particularly Amanda Fioritto, Anne Kruse, and Christine Mellen, for their time and effort in the iterative review process of this article. The author expresses her gratitude to Professor Dylan Conger for her guidance, support, and insightful comments on the paper. In addition, the author thanks Juan Ponce (FLACSO-Ecuador) for his guidance on the original research thesis that was the basis to write this paper. Lastly, the author thanks her family for their unconditional support and patience as she pursues her academic and professional goals. 